Supporting Information for

\title{
Synthesis and Activity of Fluorescent Isoprenoid
}

\section{Pyrophosphate Analogues}

MeeKyoung $\mathrm{Kim}^{\dagger}$, Troy Kleckley ${ }^{\dagger}$, Andrew J. Wiemer ${ }^{\ddagger}$, Sarah A. Holstein ${ }^{\ddagger}$, Raymond J. Hohl $^{\ddagger}$, and David F. Wiemer ${ }^{*}$

Department of Chemistry ${ }^{\dagger}$ and Departments of Internal Medicine and Pharmacology ${ }^{\ddagger}$

\author{
University of Iowa
}

Iowa City, Iowa 52242-1294

* Corresponding author. Tel: 319-335-1365; Fax: 319-335-1270; e-mail: davidwiemer@uiowa.edu 
General Experimental Procedures $\quad$ S3

${ }^{1} \mathrm{H}$ NMR Spectrum of Compound $\mathbf{1 1} \quad \mathrm{S} 4$

${ }^{13} \mathrm{C}$ NMR Spectrum of Compound $\mathbf{1 1}(100 \mathrm{MHz}) \quad$ S5

${ }^{1} \mathrm{H}$ NMR Spectrum of Compound $\mathbf{1 2}$ S6

${ }^{13} \mathrm{C}$ NMR Spectrum of Compound $12 \quad$ S7

${ }^{1} \mathrm{H}$ NMR Spectrum of Compound $5(400 \mathrm{MHz}) \quad$ S8

${ }^{13} \mathrm{C}$ NMR Spectrum of Compound $\mathbf{5}(100 \mathrm{MHz}) \quad$ S9

${ }^{31} \mathrm{P}$ NMR Spectrum of Compound $\mathbf{5} \quad \mathrm{S} 10$

${ }^{1} \mathrm{H}$ NMR Spectrum of Compound $19 \quad \mathrm{~S} 11$

${ }^{13} \mathrm{C}$ NMR Spectrum of Compound $19 \quad \mathrm{~S} 12$

${ }^{1} \mathrm{H}$ NMR Spectrum of Compound $23 \quad \mathrm{~S} 13$

${ }^{13} \mathrm{C}$ NMR Spectrum of Compound $23(100 \mathrm{MHz}) \quad \mathrm{S} 14$

$\begin{array}{ll}{ }^{1} \mathrm{H} \text { NMR Spectrum of Compound } 24 & \text { S15 }\end{array}$

${ }^{13} \mathrm{C}$ NMR Spectrum of Compound $\mathbf{2 4} \quad \mathrm{S} 16$

$\begin{array}{ll}{ }^{1} \mathrm{H} \text { NMR Spectrum of Compound } 27 & \text { S17 }\end{array}$

${ }^{13} \mathrm{C}$ NMR Spectrum of Compound $27 \quad \mathrm{~S} 18$

${ }^{31}$ P NMR Spectrum of Compound 27 $\quad$ S19

${ }^{1}$ H NMR Spectrum of Compound $29 \quad$ S20

${ }^{13}$ C NMR Spectrum of Compound $29 \quad$ S21

${ }^{1} \mathrm{H}$ NMR Spectrum of Compound $33 \quad$ S22

${ }^{13} \mathrm{C}$ NMR Spectrum of Compound $33 \quad$ S23

${ }^{1} \mathrm{H}$ NMR Spectrum of Compound $36 \quad$ S24

${ }^{13}$ C NMR Spectrum of Compound $36 \quad$ S25

${ }^{31} \mathrm{P}$ NMR Spectrum of Compound $36 \quad$ S26

$\begin{array}{ll}\text { Sulfonamide } 22 & \text { S27 }\end{array}$

$\begin{array}{ll}\text { Sulfonamide } 23 & \text { S27 }\end{array}$

$\begin{array}{ll}\text { Geranylgeraniol analogue } 24 & \text { S28 }\end{array}$

Sulfonamide $25 \quad$ S28

Sulfonamide $32 \quad$ S29

Geranylgeraniol analogue $\mathbf{2 4} \quad$ S30

$\begin{array}{ll}\text { Chloride } 34 & \text { S30 }\end{array}$ 


\section{General Experimental Procedures}

THF was freshly distilled from sodium/benzophenone, while dichloromethane, acetonitrile, and triethylamine were freshly distilled from calcium hydride. All reactions in nonaqueous solvents were conducted in oven-dried glassware, under a positive pressure of argon, with magnetic stirring. Flash column chromatography was carried out on silica gel with $40 \mu \mathrm{m}$ average particle diameter, while reverse phase chromatography was done on C18 silica gel with 40-75 mm particle size, and ion exchange chromatography employed an AG 50W-X8 resin with 100-200 mesh (hydrogen form, 1.7 mequ/mL). NMR spectra were recorded on either a Brucker AC-300 or a DPX-300 $\mathrm{MHz}$, instrument $\left({ }^{1} \mathrm{H}\right.$ at $300 \mathrm{MHz}$, and ${ }^{13} \mathrm{C}$ at $75 \mathrm{MHz}$ ), or on a Brucker DRX-400 MHz, instrument $\left({ }^{1} \mathrm{H}\right.$ at $400 \mathrm{MHz}$, and ${ }^{13} \mathrm{C}$ at $\left.100 \mathrm{MHz}\right)$ if so noted. Spectra were obtained in $\mathrm{CDCl}_{3}$ solution unless otherwise noted, with $\left(\mathrm{CH}_{3}\right)_{4} \mathrm{Si}\left({ }^{1} \mathrm{H} 0.0 \mathrm{ppm}\right)$ or $\mathrm{CDCl}_{3}\left({ }^{13} \mathrm{C}, 77.23\right.$ ppm) as internal standards. All ${ }^{31} \mathrm{P}$ NMR chemical shifts are reported in ppm relative to 85\% $\mathrm{H}_{3} \mathrm{PO}_{4}$ (external standard). Excitation/Emission spectra were recorded on SIMAMINCO 48000 MHF. High-resolution mass spectra were obtained at the University of Iowa Mass Spectrometry Facility. Elemental analyses were performed by Atlantic Microlab Inc. (Norcross, GA). 


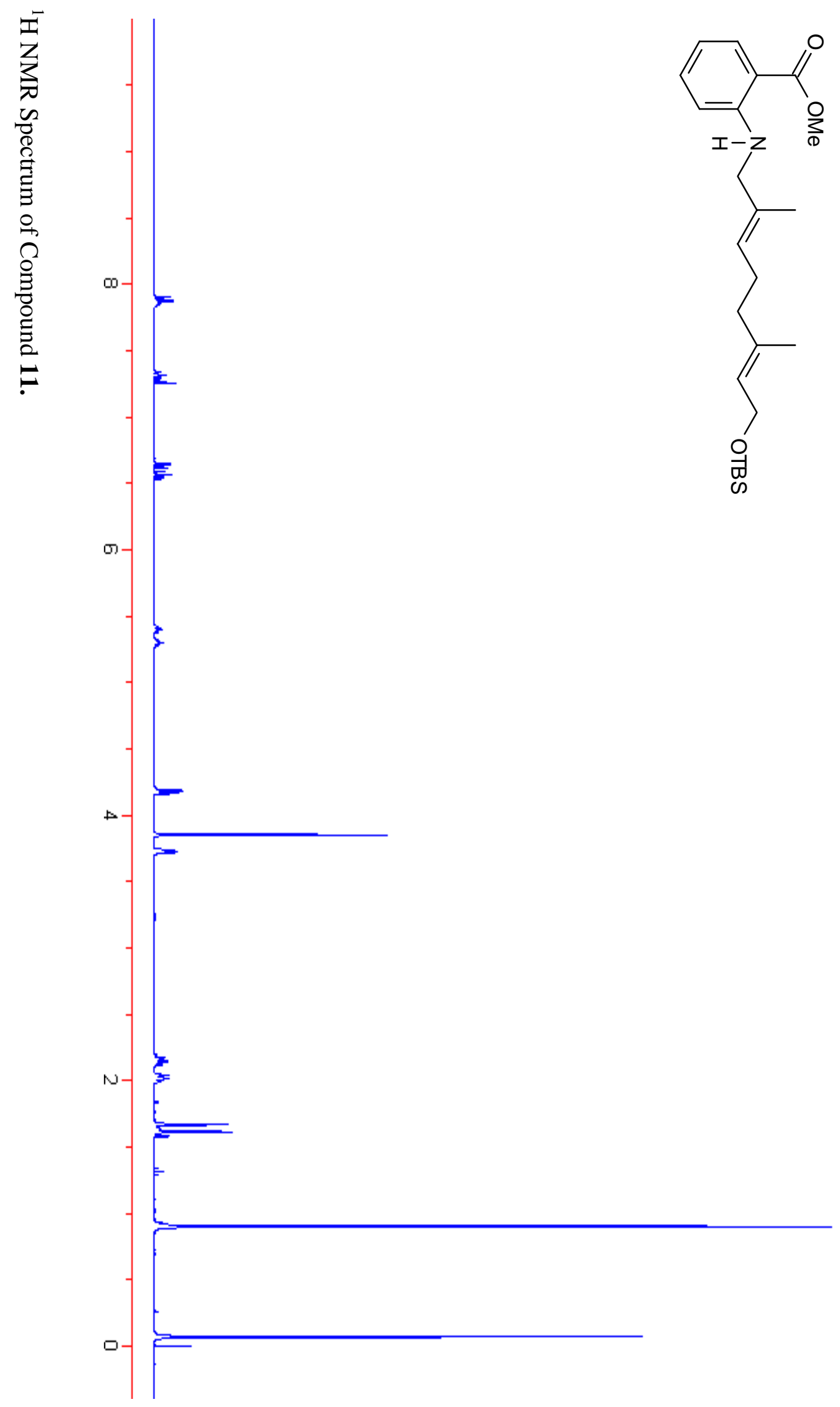




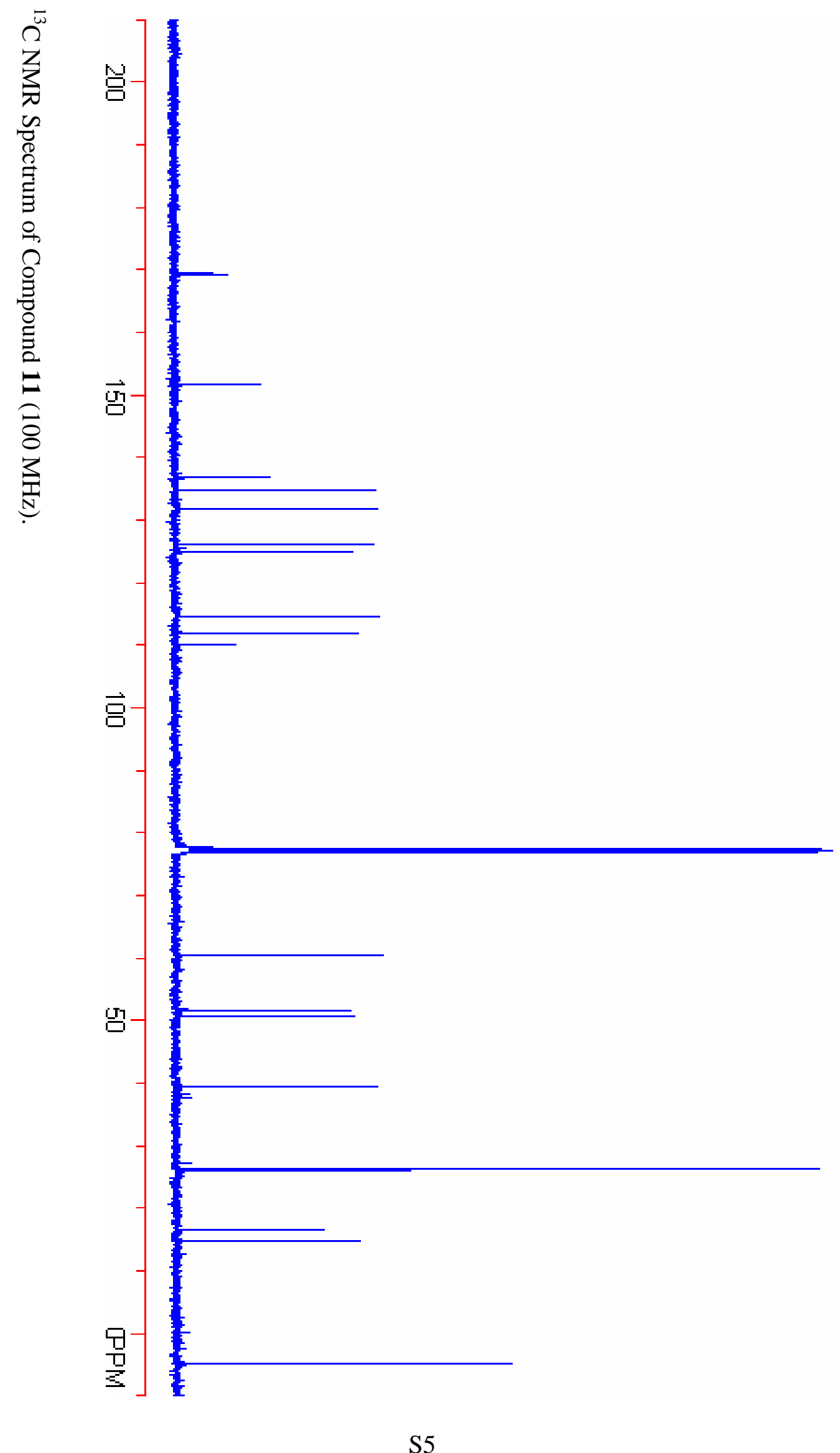




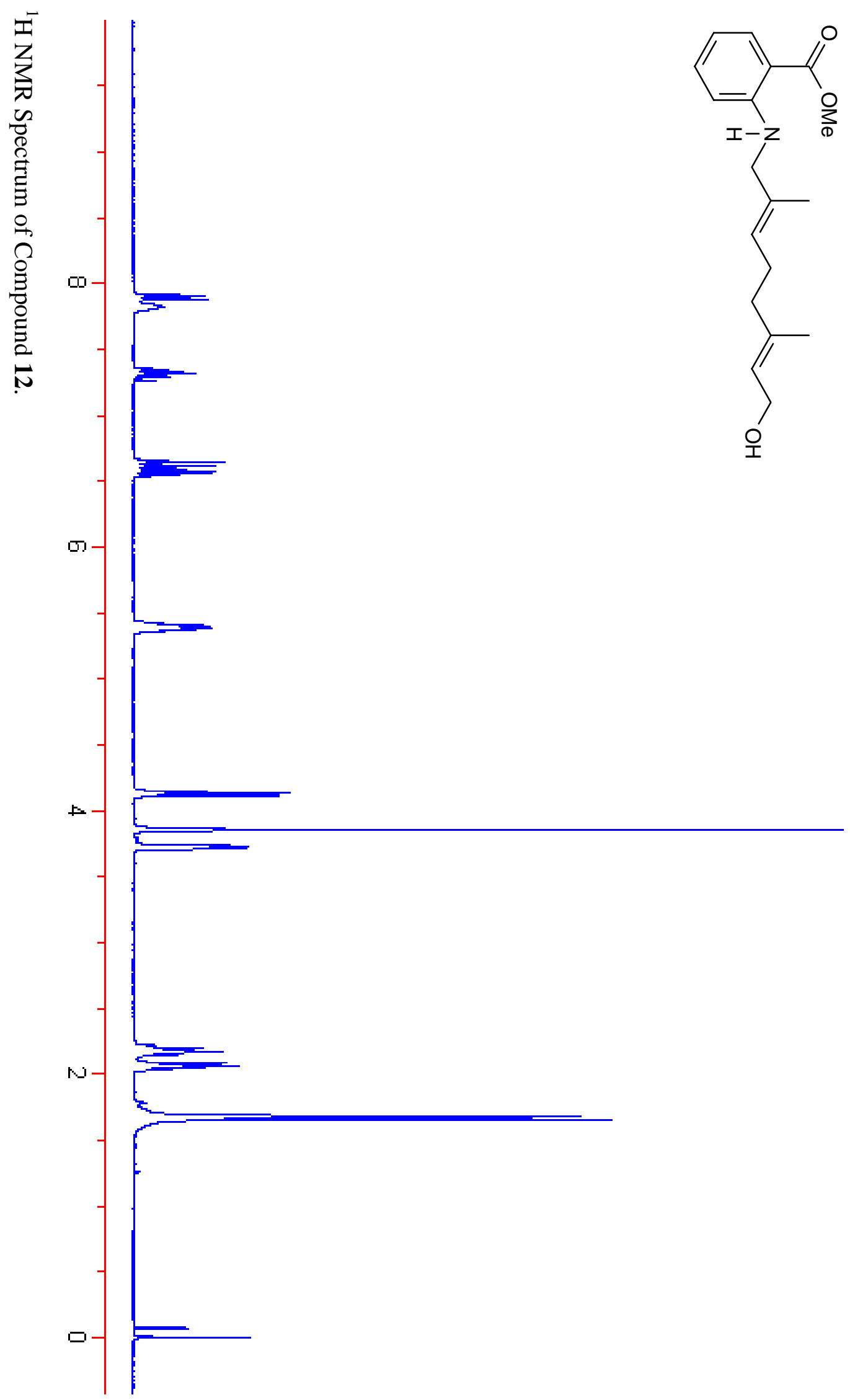




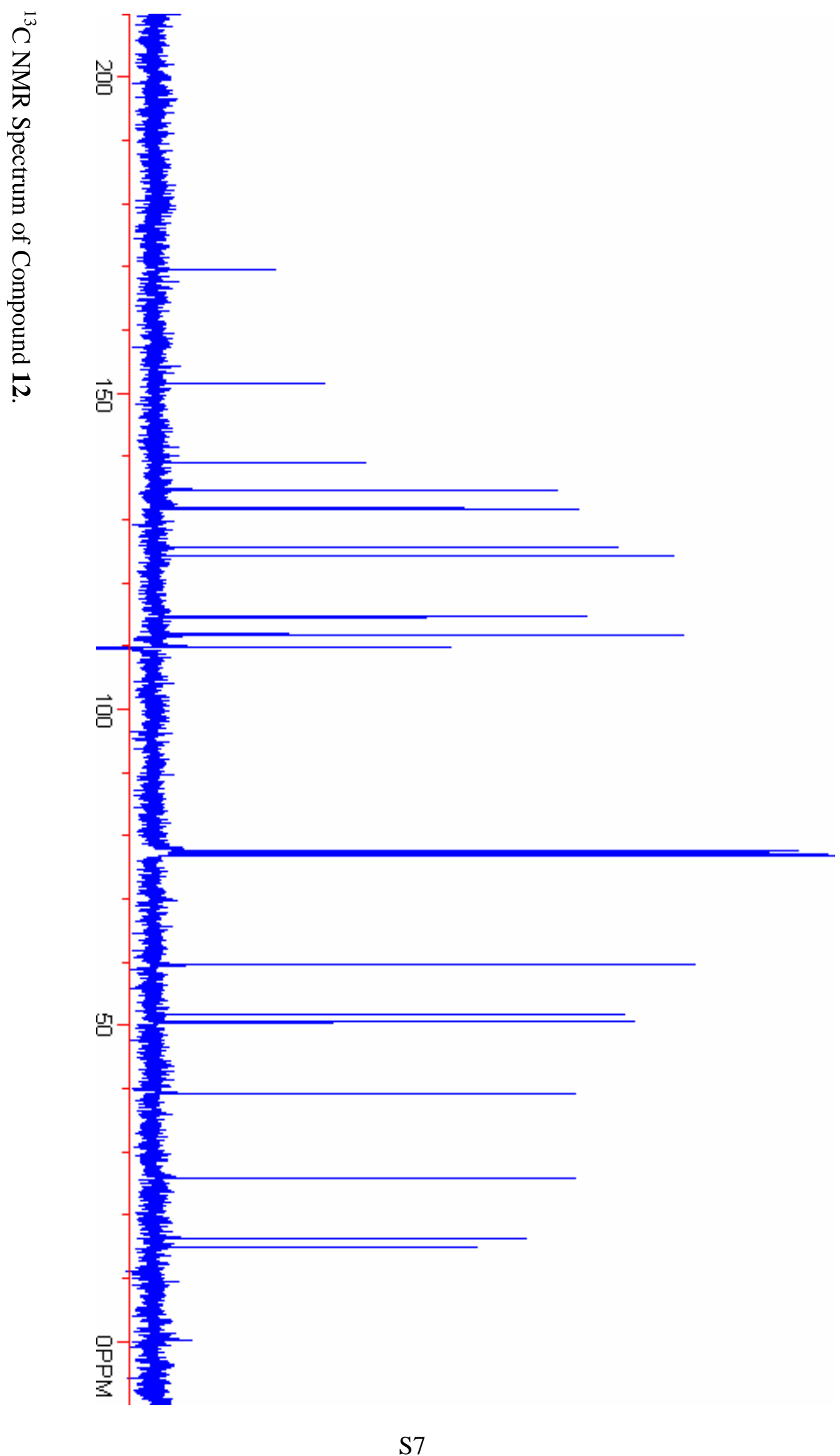




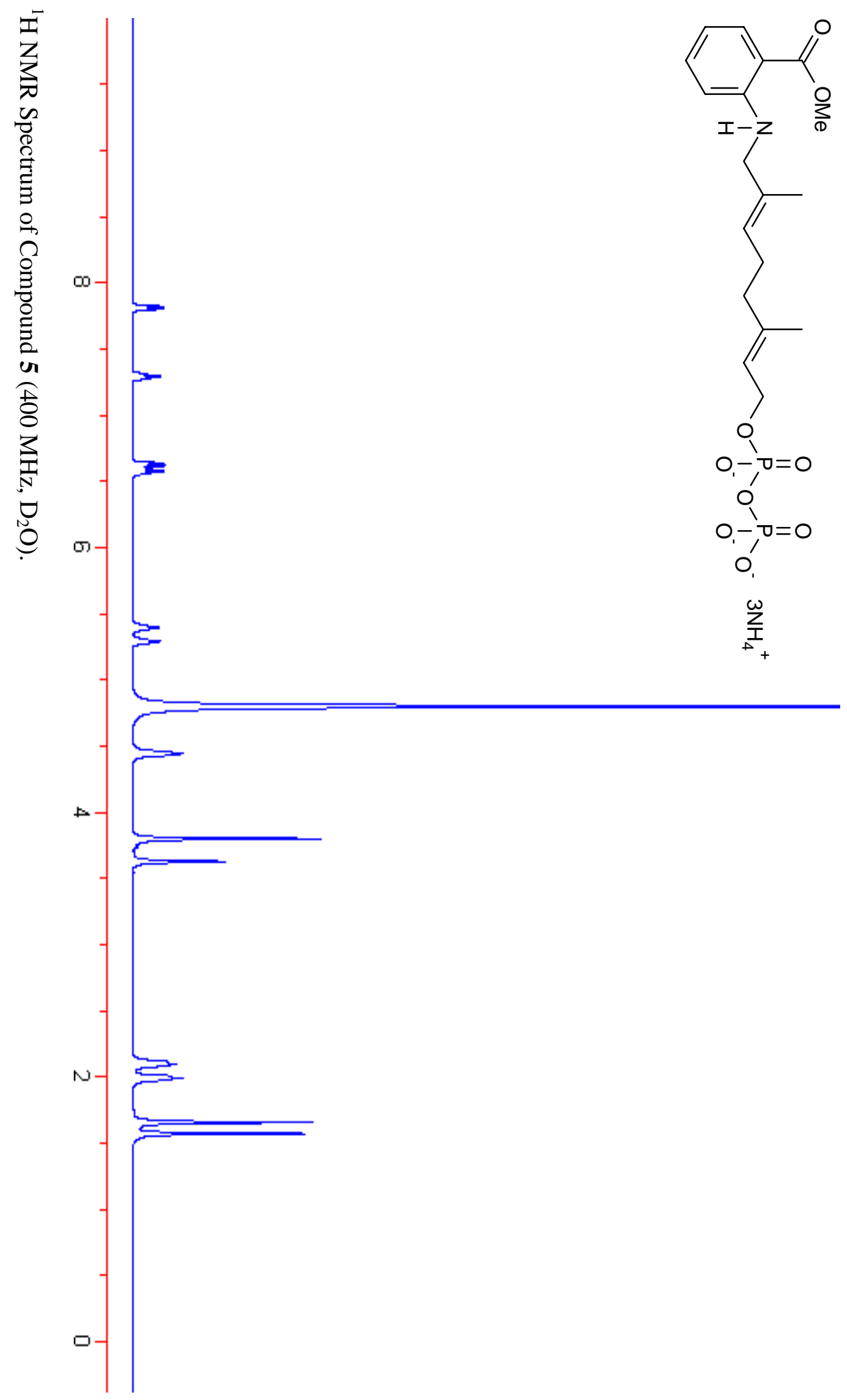




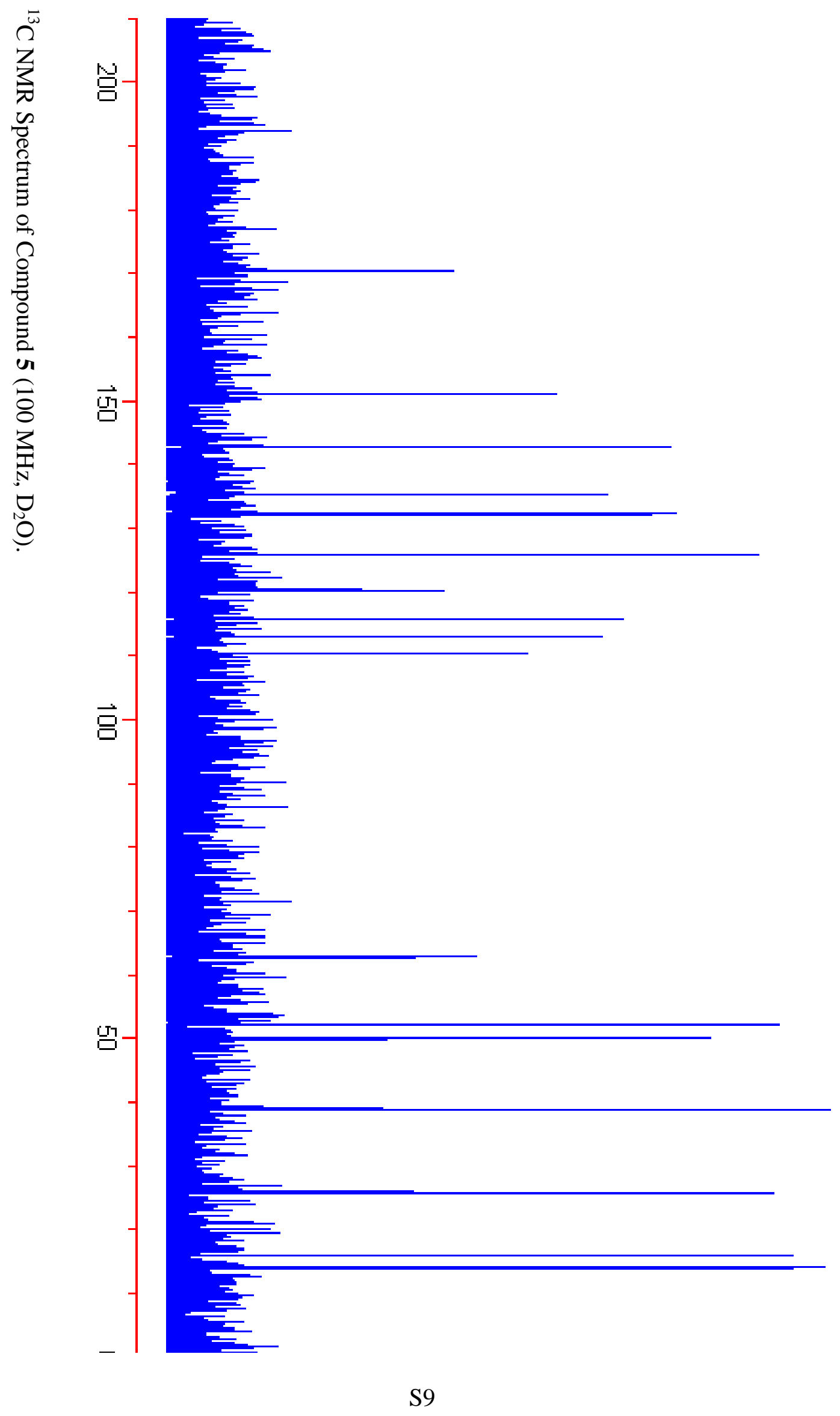




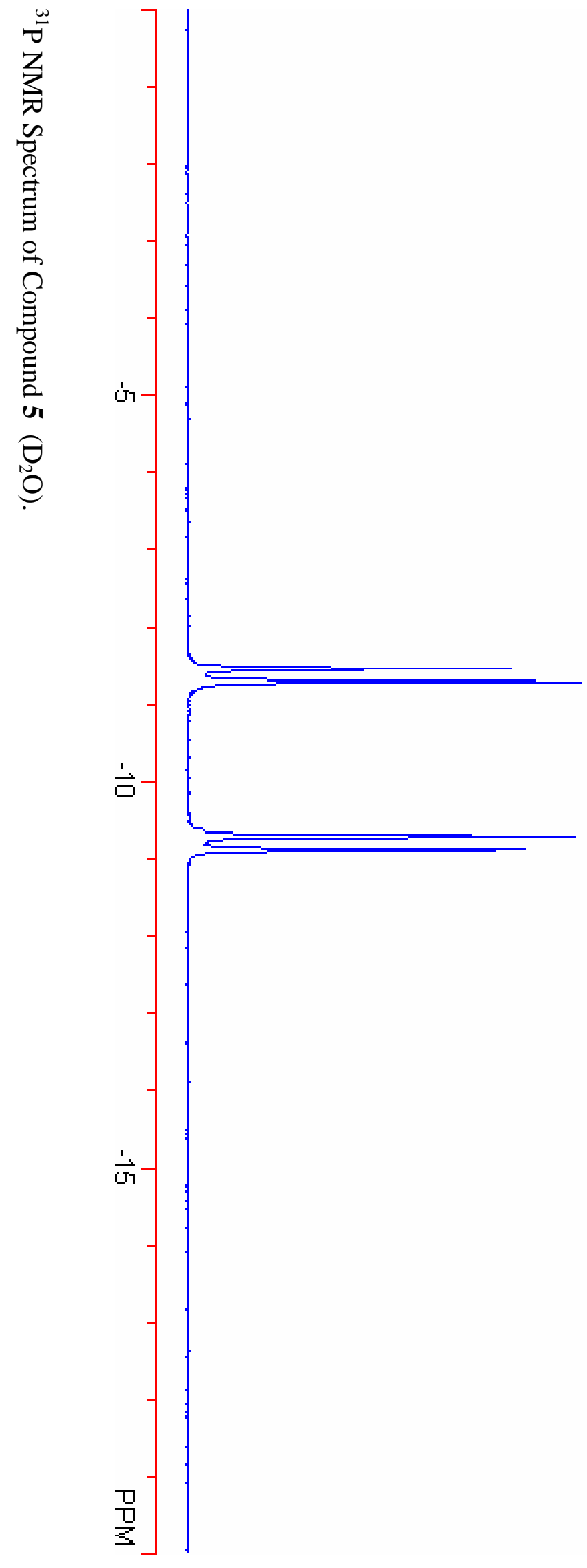




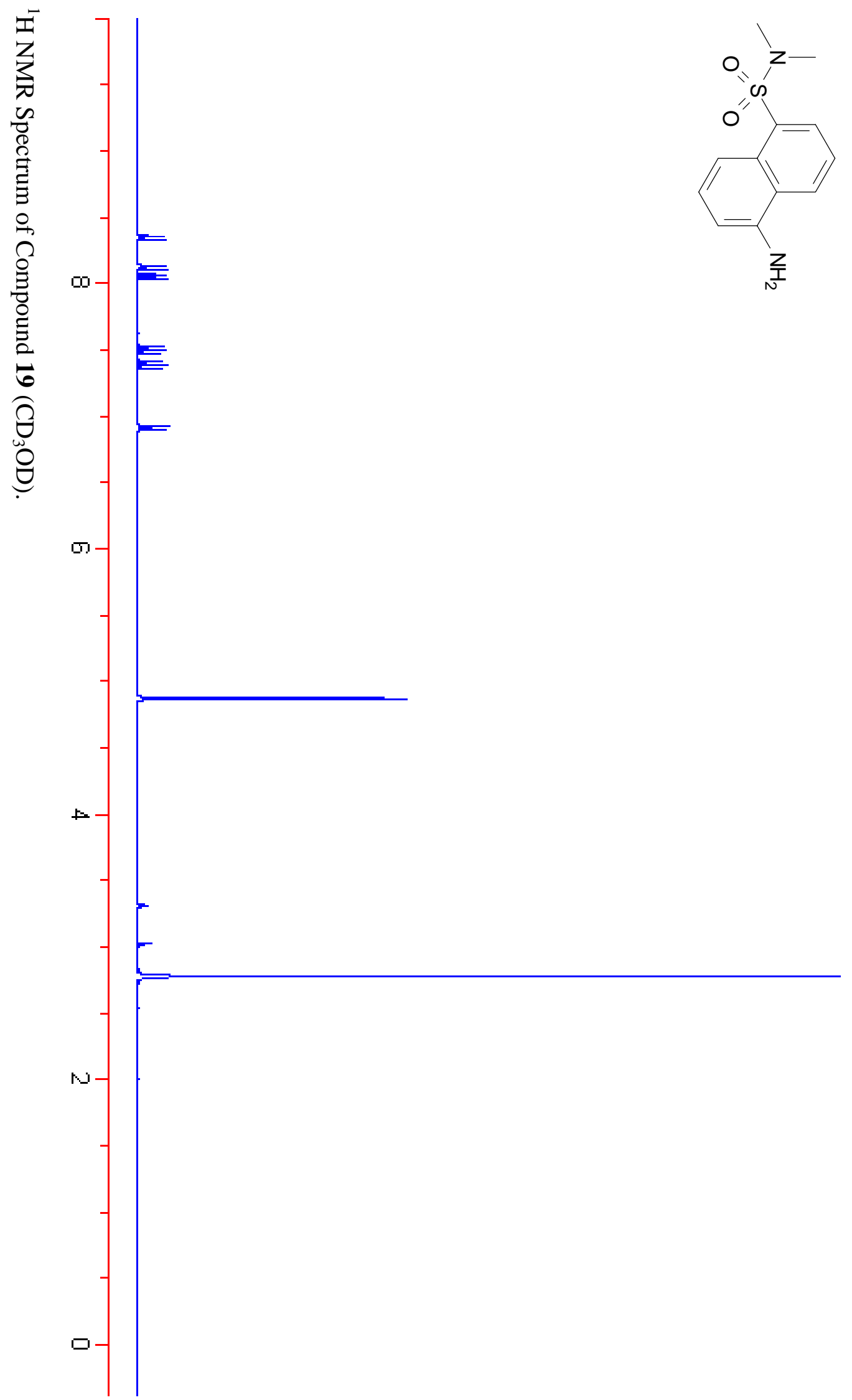




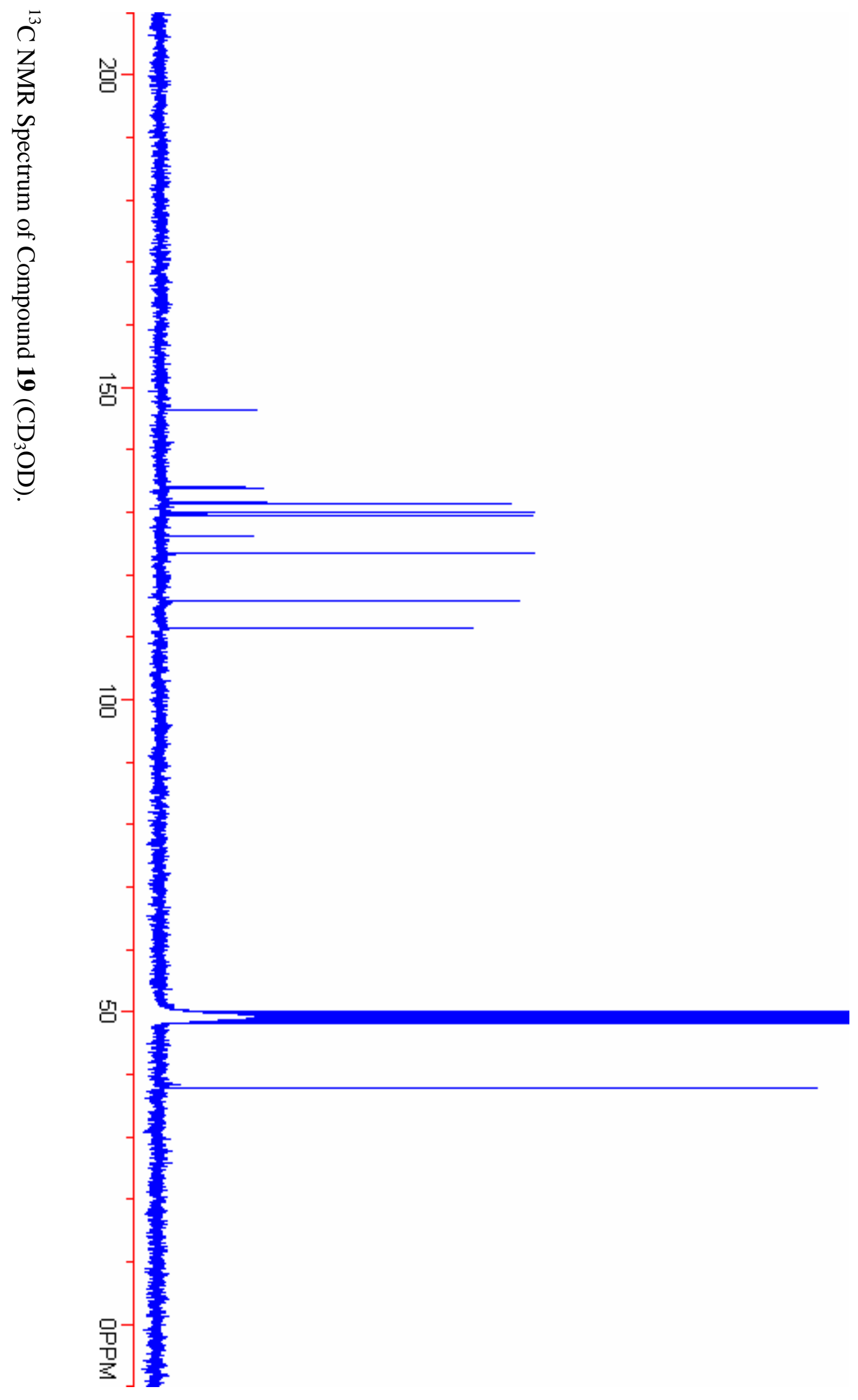

S12 


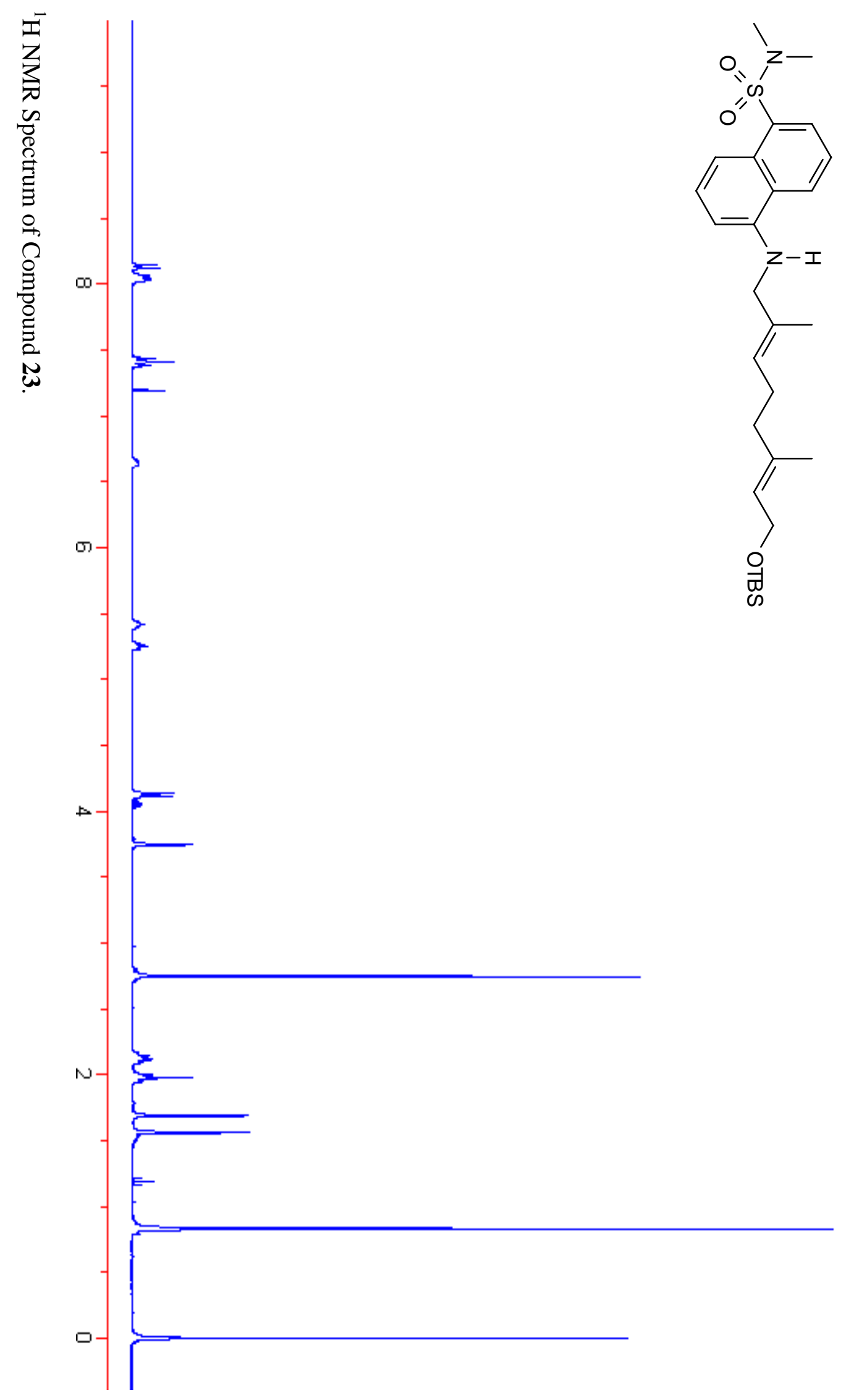




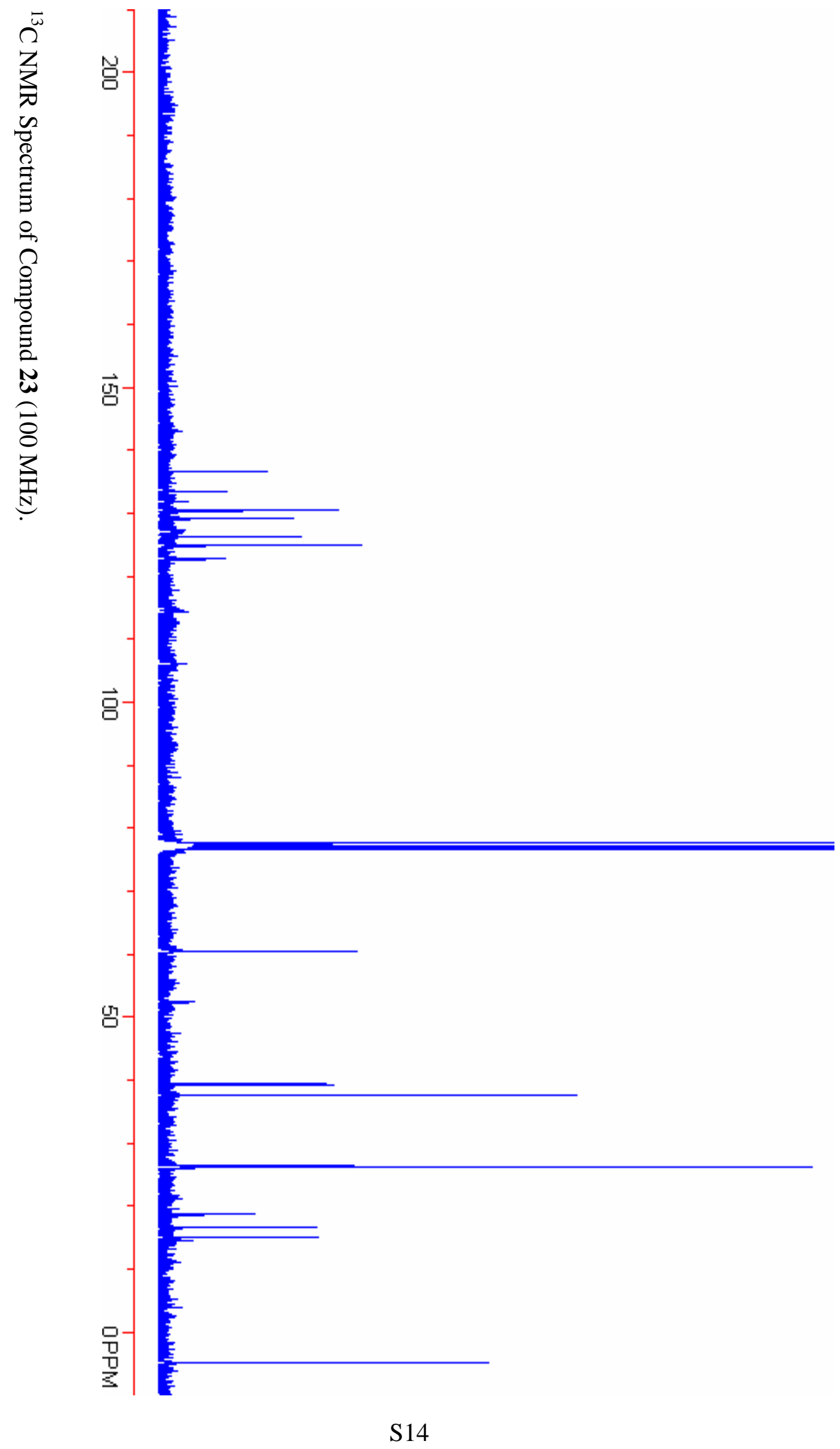




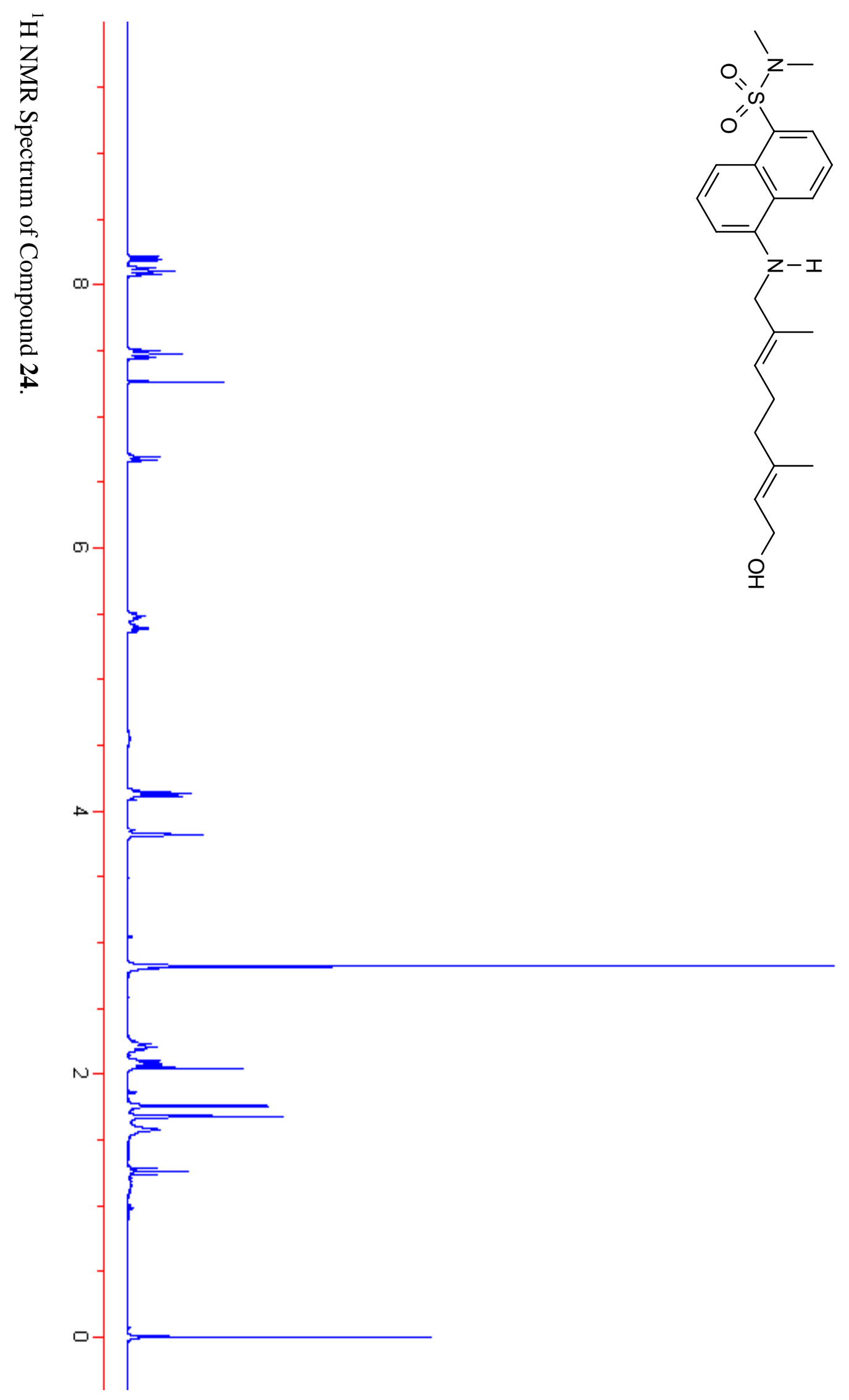




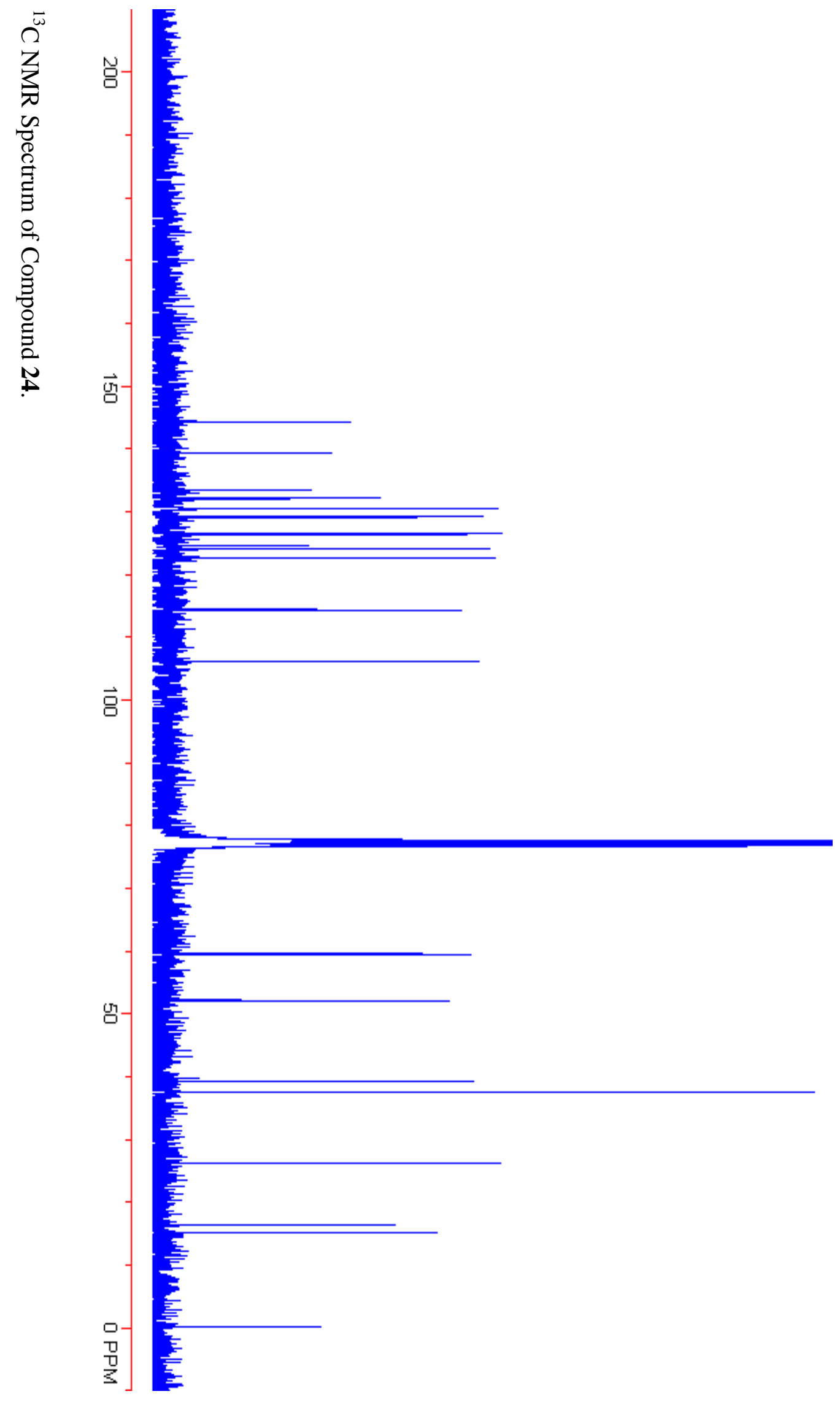

S16 


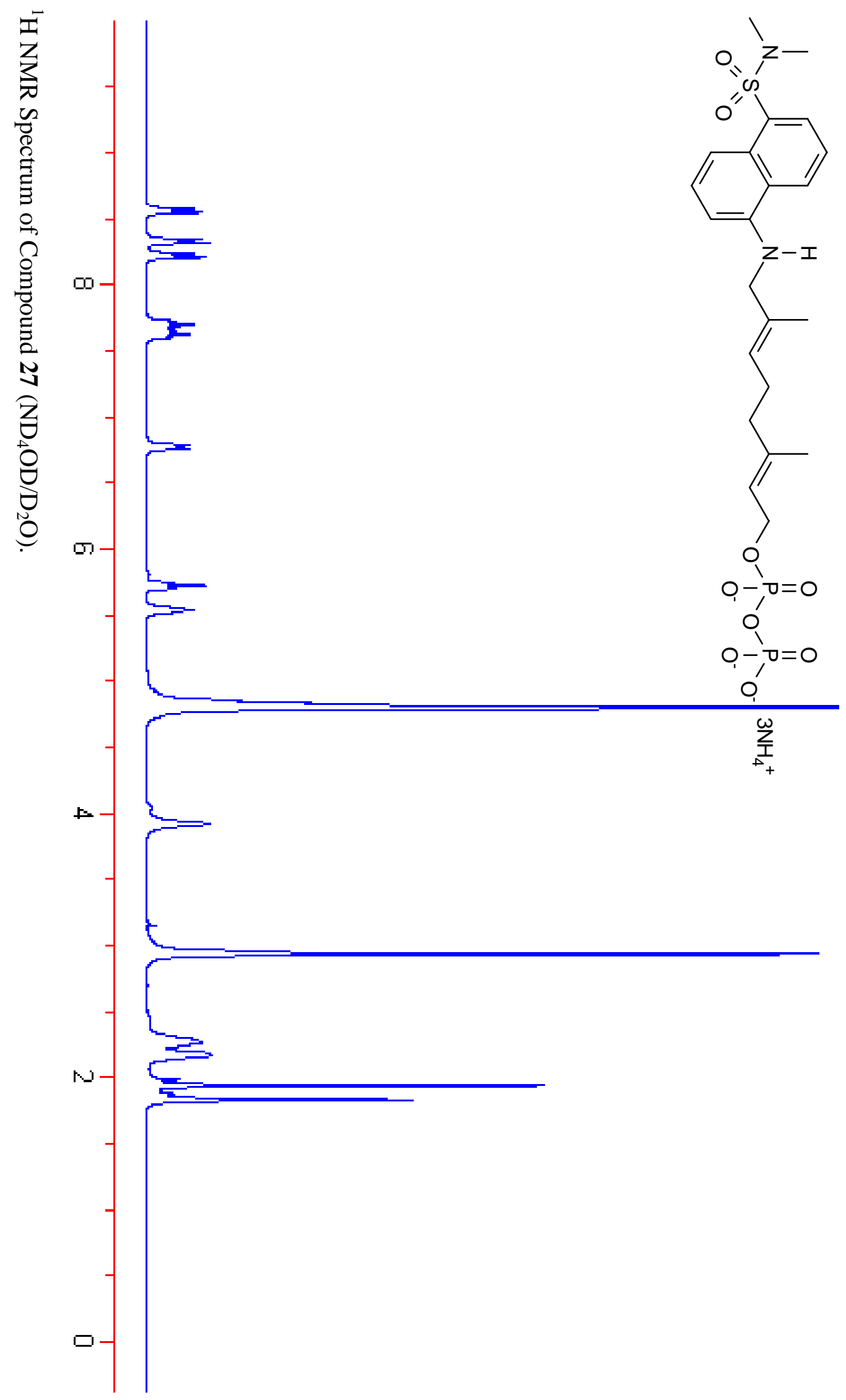




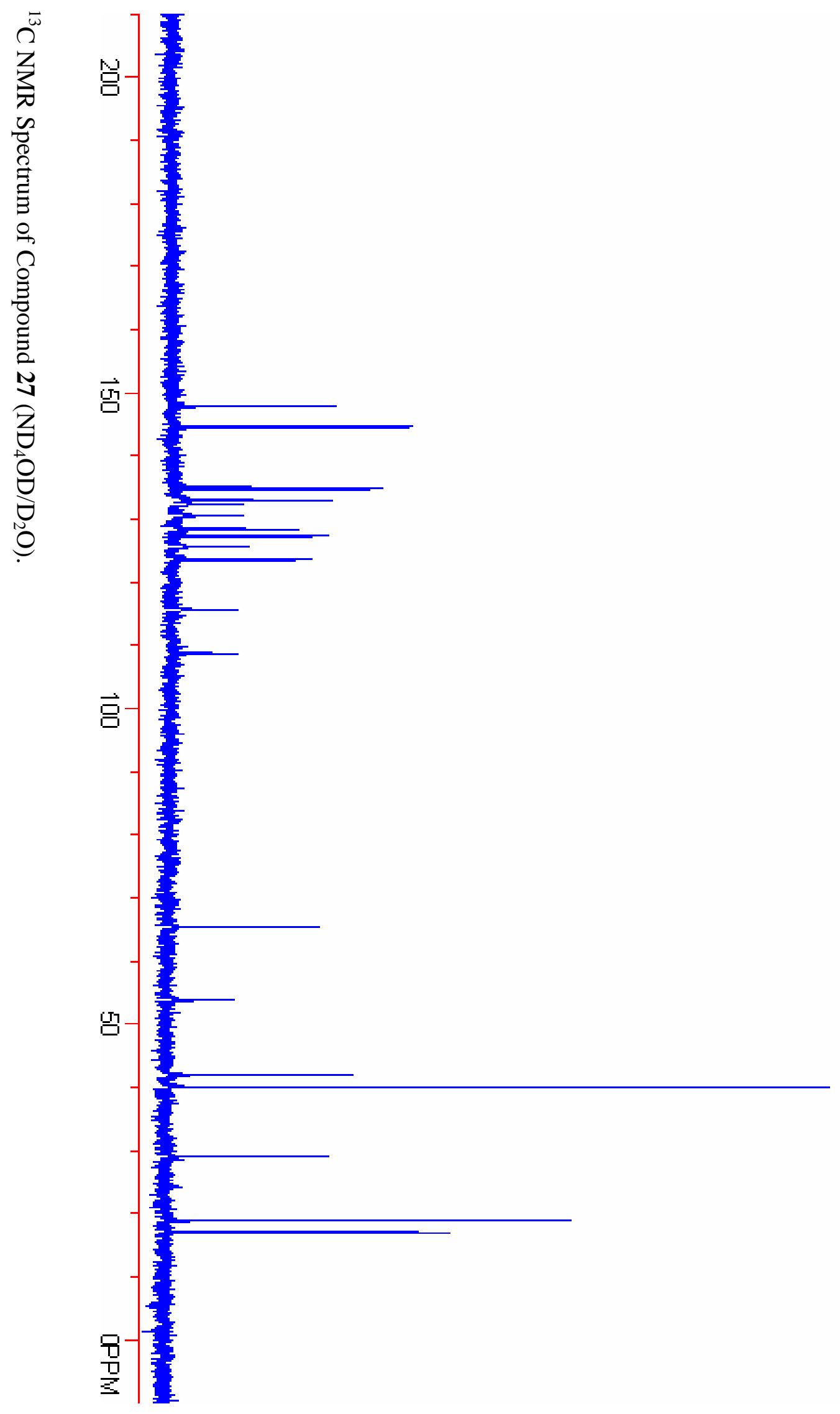

S18 


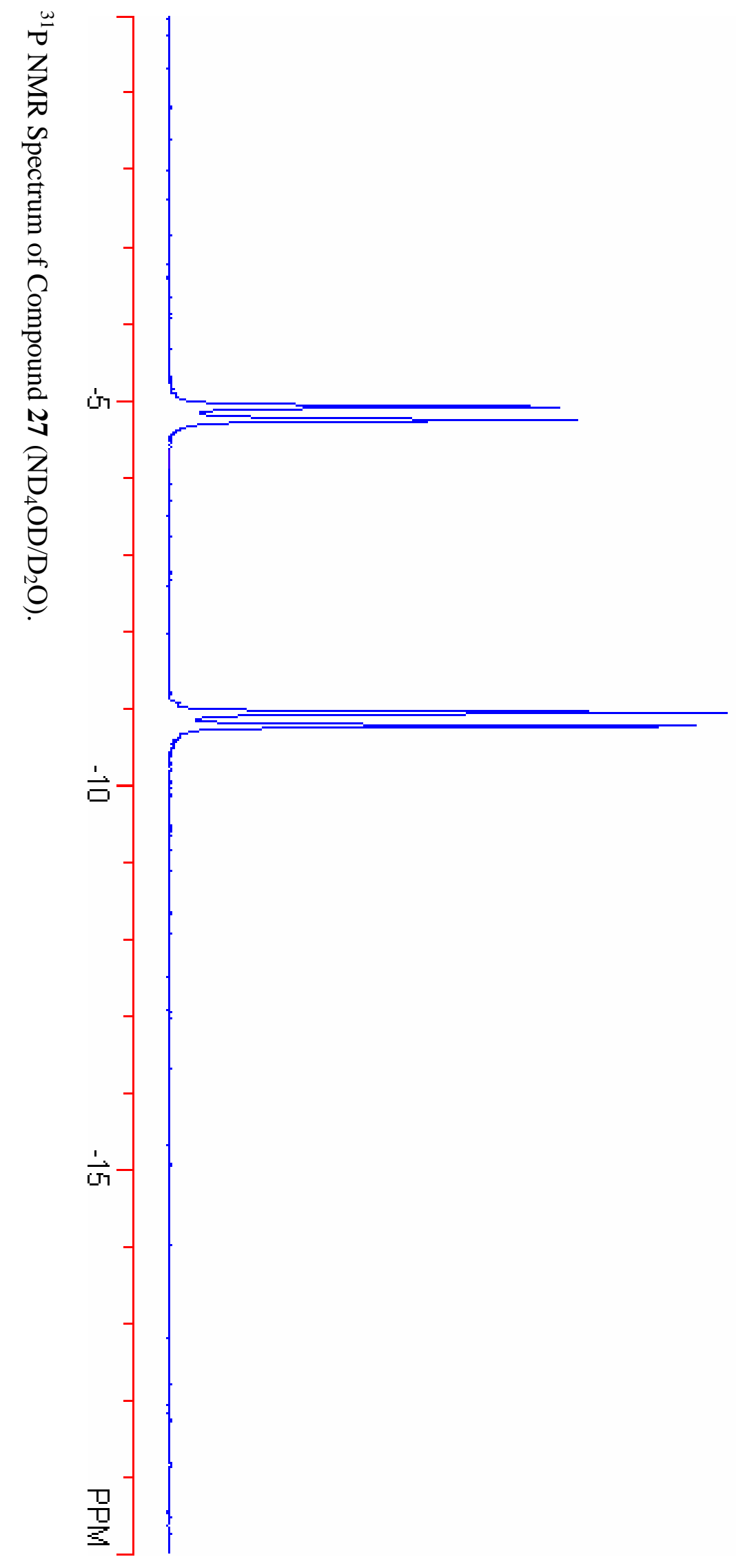




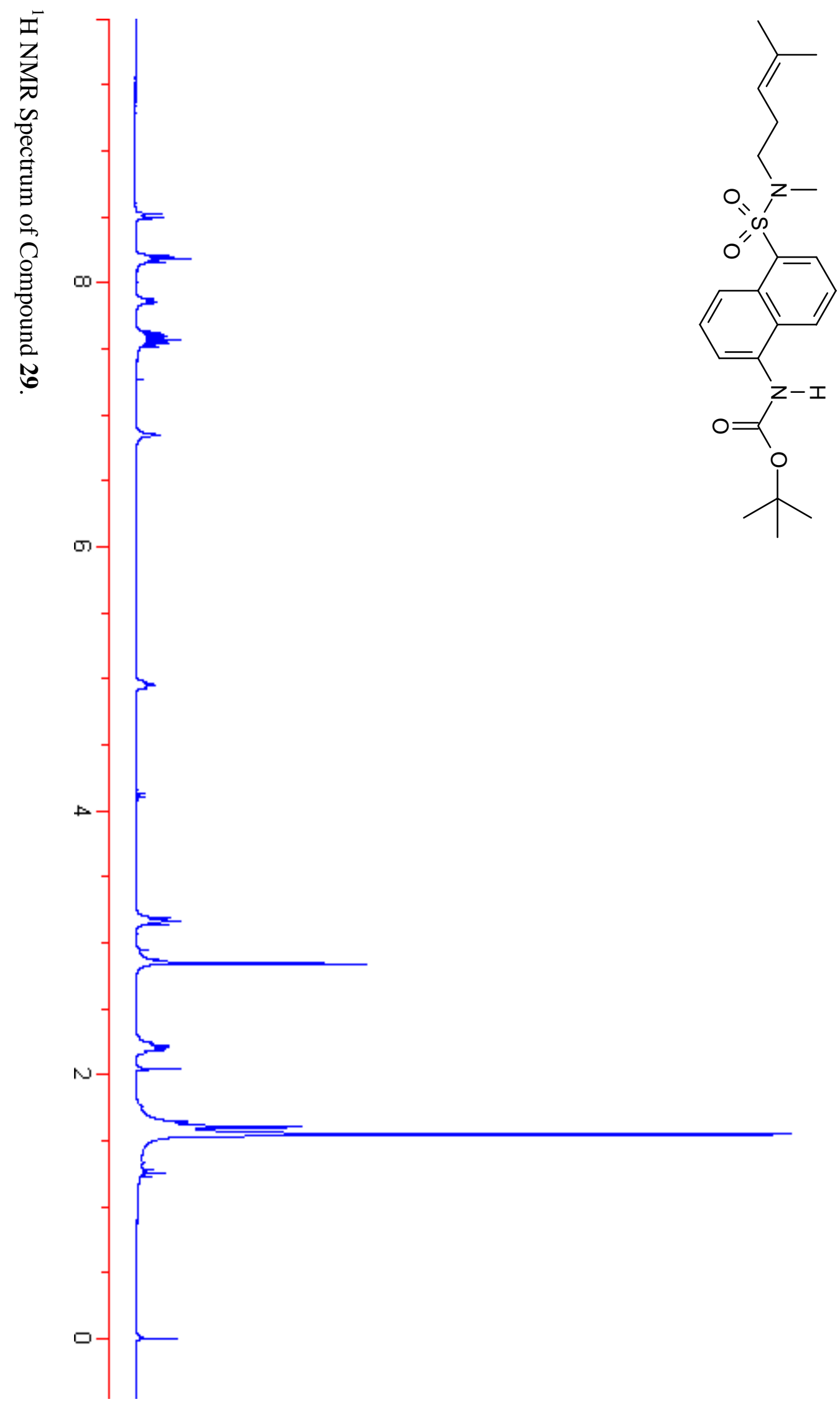




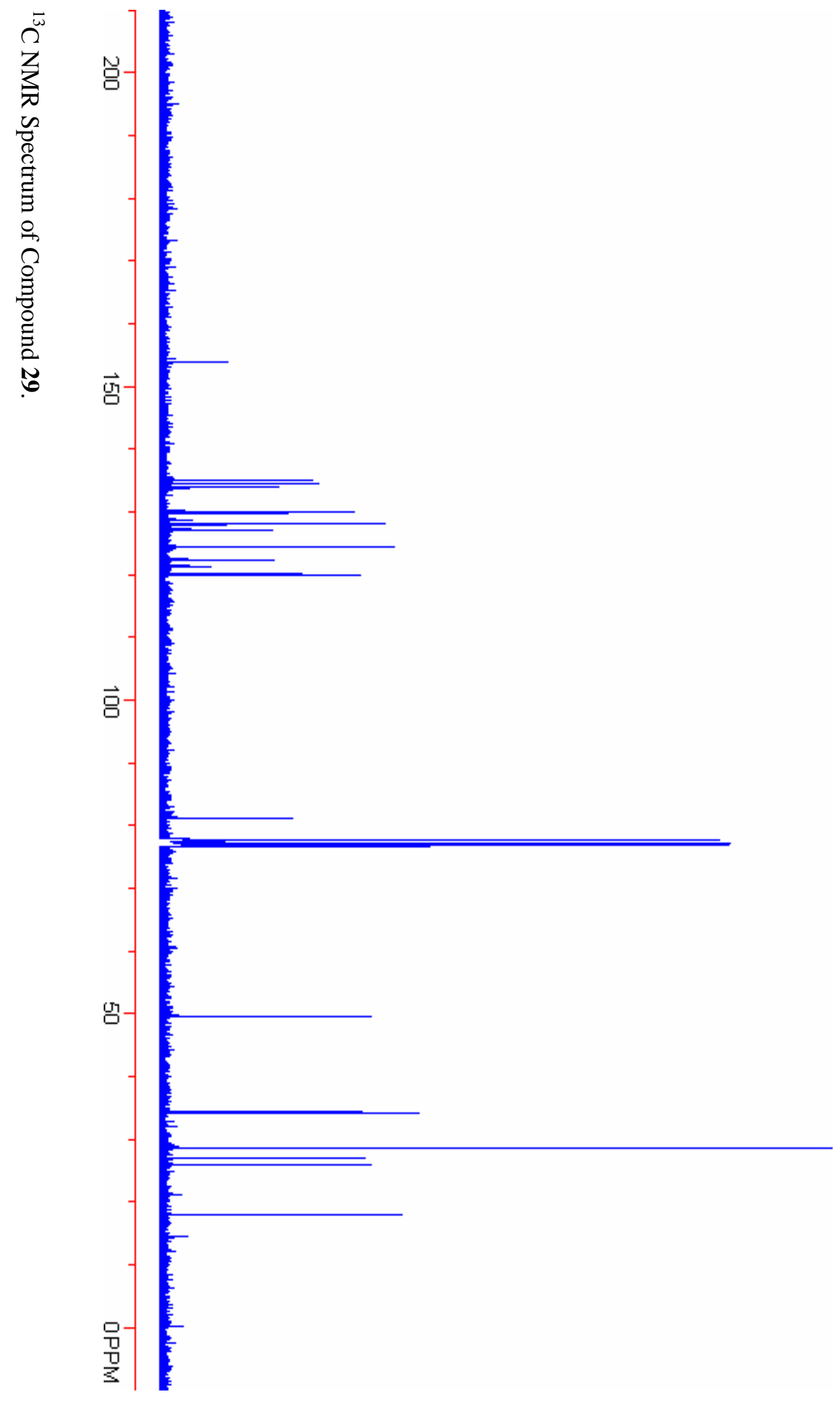

S21 


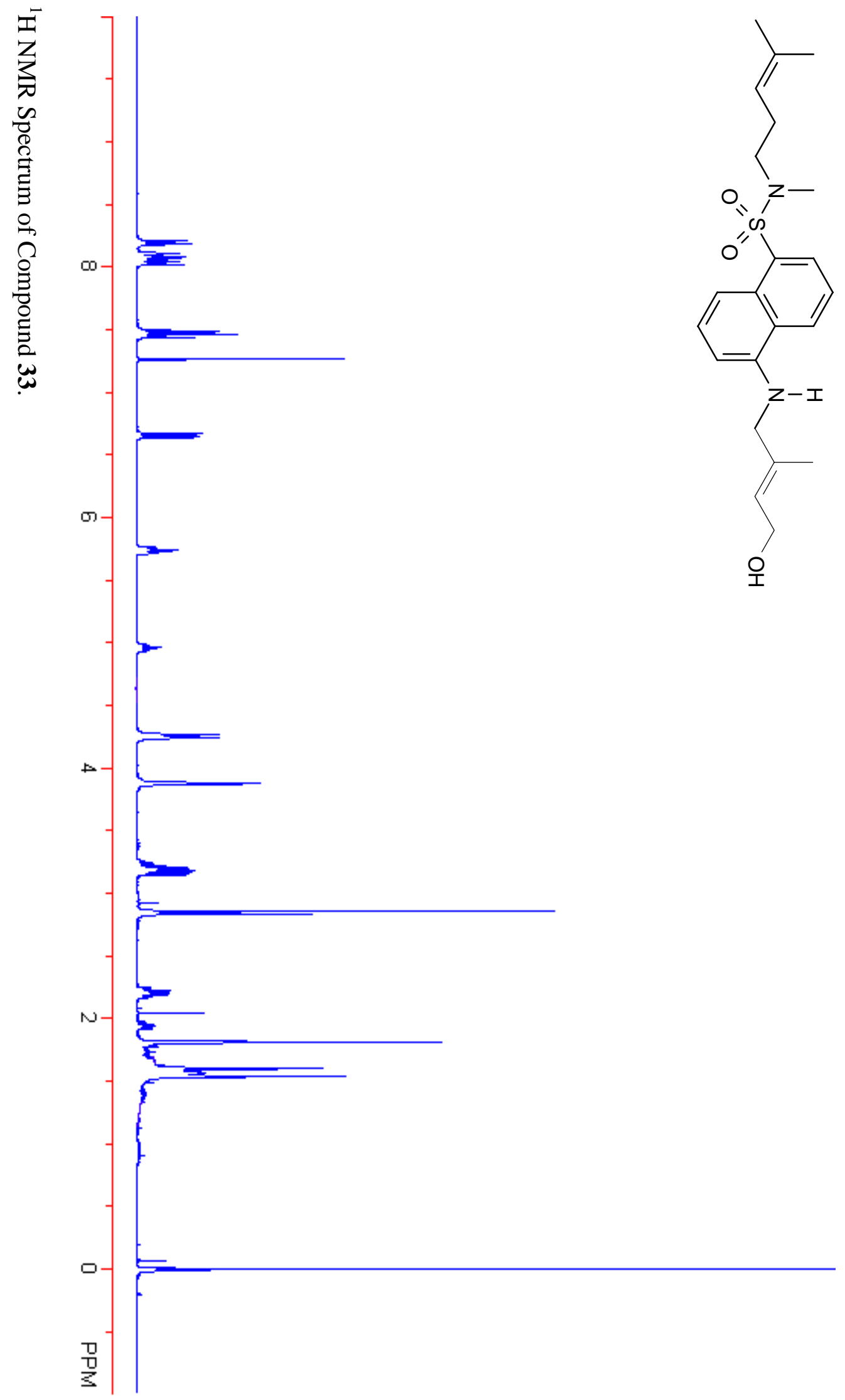




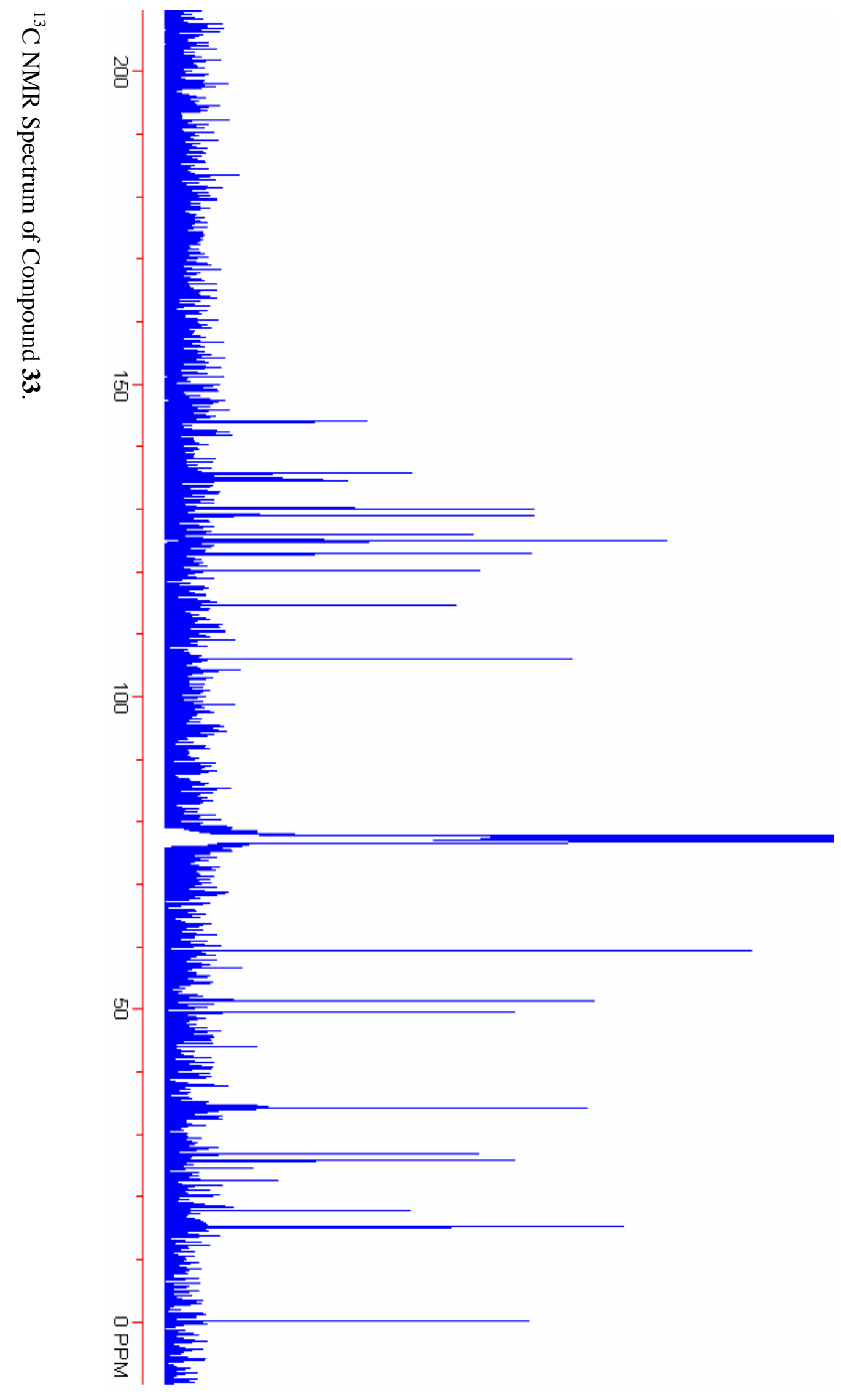

S23 


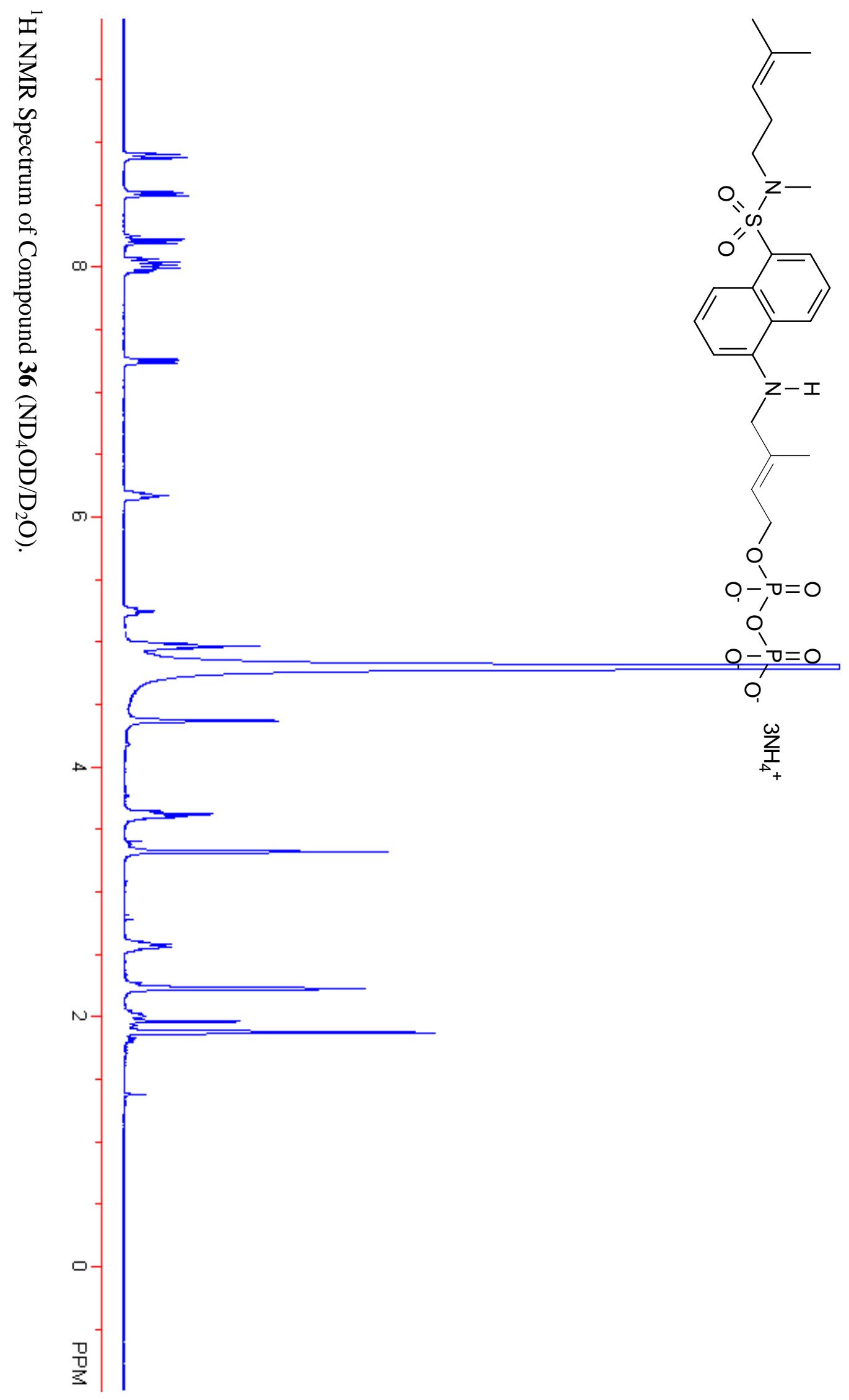




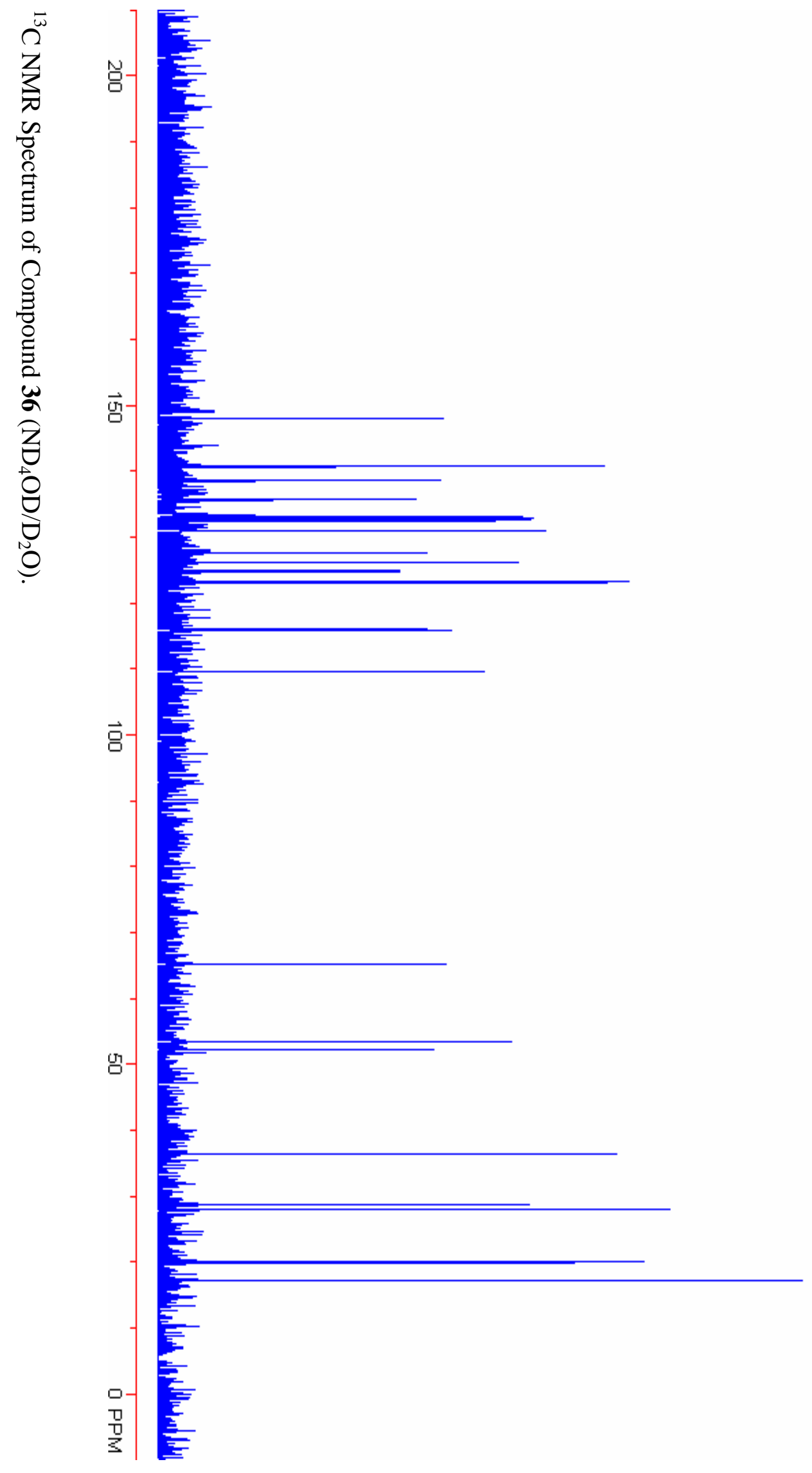




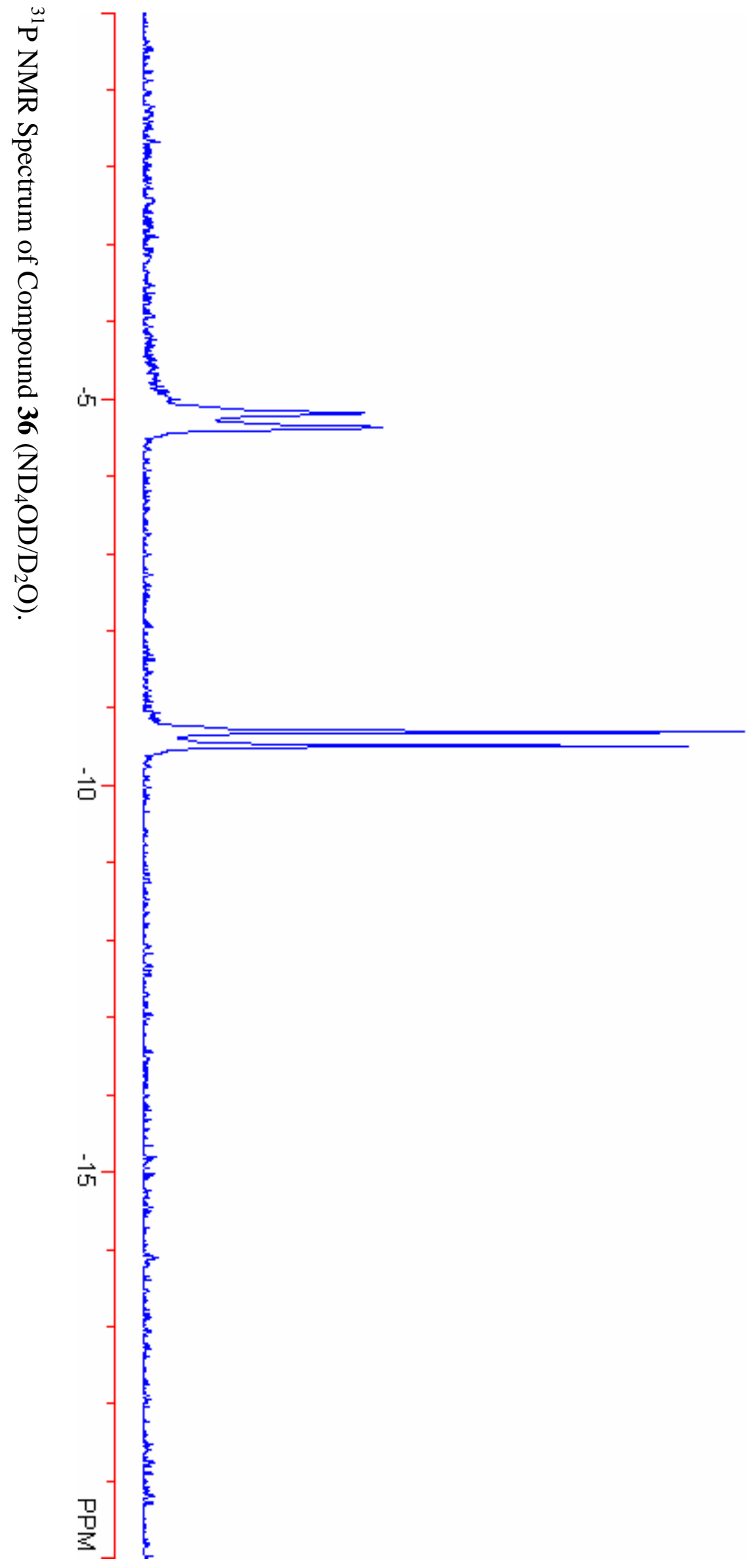


Sulfonamide 22. To a solution of compound 19 (677 mg, $2.04 \mathrm{mmol})$ and aldehyde 8 (472 mg, $2.25 \mathrm{mmol})$ in dichloroethane $(8 \mathrm{~mL})$ was added HOAc $(0.14 \mathrm{~mL}$, $2.45 \mathrm{mmol}$ ) and $4 \AA$ molecular sieves and the solution was stirred briefly at rt. Solid $\mathrm{NaBH}(\mathrm{OAc})_{3}$ (605 mg, $2.85 \mathrm{mmol}$ ) was added and the resulting solution was stirred for $24 \mathrm{~h}$. The solution then was quenched slowly by addition of $5 \% \mathrm{NaHCO}_{3}$, extracted with EtOAc, and the combined extracts were dried $\left(\mathrm{MgSO}_{4}\right)$. After concentration of the extracts under reduced pressure, the residue was purified by column chromatography (hexane:EtOAc, 9:1) to afford compound 22 (453 mg, 50\%) as a colorless oil: ${ }^{1} \mathrm{H}$ NMR $\delta$ 8.20 (dd, $J=7.3,1.0 \mathrm{~Hz}, 1 \mathrm{H}), 8.13$ (d, $J=9.4 \mathrm{~Hz}, 1 \mathrm{H}), 8.10$ (d, $J=8.8 \mathrm{~Hz}, 1 \mathrm{H}), 7.50-$ 7.44 (m, 2H), 6.68 (d, $J=7.7 \mathrm{~Hz}, 1 \mathrm{H}), 5.47$ (t, $J=6.9 \mathrm{~Hz}, 1 \mathrm{H}), 5.37-5.33$ (m, 1H), 4.59 (d, $J=6.9 \mathrm{~Hz}, 3 \mathrm{H}$ ), 3.82 (s, 2H), 2.82 (s, 6H), 2.24-2.18 (m, 2H), 2.13-2.07 (m, 2H), 2.04 (s, 3H), 1.75 (s, 3H), 1.73 (s, 3H). Anal. Calcd for $\mathrm{C}_{24} \mathrm{H}_{32} \mathrm{O}_{4} \mathrm{~N}_{2} \mathrm{~S}$ : C, 64.84; H 7.25; N, 6.30. Found: C, 64.73; H 7.31; N, 6.25.

Sulfonamide 23. To a solution of compound 19 (1.47 g, $4.44 \mathrm{mmol})$ and aldehyde 9 ( $3.54 \mathrm{~g}, 12.5 \mathrm{mmol})$ in dichloroethane (17.5 mL) was added HOAc (2.1 mL, $36.0 \mathrm{mmol}$ ) and $4 \AA$ molecular sieves and the resulting solution was stirred briefly at rt. After $\mathrm{NaBH}(\mathrm{OAc})_{3}(5.65 \mathrm{~g}, 26.6 \mathrm{mmol})$ was added, the reaction solution was stirred for $24 \mathrm{~h}$. The solution was quenched by addition of $5 \% \mathrm{NaHCO}_{3}$, extracted with EtOAc, and the combined organic layers were dried $\left(\mathrm{MgSO}_{4}\right)$. After concentration of the extracts, the residue was purified by column chromatography (hexane:EtOAc, 8:2) to afford compound 23 (2.02 g, 88\%) as a green-yellow oil: ${ }^{1} \mathrm{H}$ NMR $\delta 8.17$ (d, $J=7.3 \mathrm{~Hz}, 1 \mathrm{H}$ ), 8.11-8.06 (m, 2H), 7.47 (d, $J=8.2 \mathrm{~Hz}, 1 \mathrm{H}), 7.44$ (dd, $J=8.7,1.9 \mathrm{~Hz}, 1 \mathrm{H}), 6.68$ (d, $J=$ $6.8 \mathrm{~Hz}, 1 \mathrm{H}$ ), 5.47 (dt, $J=7.0,1.0 \mathrm{~Hz}, 1 \mathrm{H}), 5.30$ (dt, $J=6.4,1.1 \mathrm{~Hz}, 1 \mathrm{H}), 4.35$ (d, $J=6.4$ 
Hz, 2H) 3.79 (s, 2H), 2.79 (s, 6H), 2.15-2.14 (m, 2H), 2.05-2.0 (m, 2H), 1.74 (s, 3H),

1.61 (s, 3H), 0.88 (s, 9H), 0.05 (s, 6H); ${ }^{13} \mathrm{C}$ NMR (100 MHz) $\delta$ 144.1, 136.4, 133.1, 131.8, 130.3, 130.2, 128.9, 126.8, 126.0, 124.7, 124.4, 122.4, 114.1, 105.8, 60.3, 52.1, 39.1, 37.4 (2C), 26.1, 26.0 (3C), 18.4, 16.4, 14.9, -5.0 (2C). Anal. Calcd for $\mathrm{C}_{28} \mathrm{H}_{44} \mathrm{~N}_{2} \mathrm{O}_{3} \mathrm{SSi}$ C, 65.07; H 8.58; N, 5.43. Found: C, 64.97; H 8.64; N, 5.33.

Geranylgeraniol analogue 24. To a solution of compound 23 (895 mg, 1.73 mmol) in THF $(10 \mathrm{~mL})$ was added TBAF (1 M solution in THF, $8.54 \mathrm{mmol})$ and the solution was stirred for $2 \mathrm{~h}$ at $0{ }^{\circ} \mathrm{C}$. The reaction was quenched by addition of saturated $\mathrm{NH}_{4} \mathrm{Cl}(\mathrm{aq})$, extracted with EtOAc, and the combined organic layers were dried $\left(\mathrm{MgSO}_{4}\right)$. After concentration in vacuo, the residue was purified by column chromatography (hexane:EtOAc, 6:4) to afford compound 24 (684 mg, 98\%) as a green-yellow oil: ${ }^{1} \mathrm{H}$ NMR $\delta 8.20$ (dd, $J=7.3,1.0 \mathrm{~Hz}, 1 \mathrm{H}), 8.12(\mathrm{~d}, J=7.7 \mathrm{~Hz}, 1 \mathrm{H}), 8.09$ (d, $J=8.4 \mathrm{~Hz}, 1 \mathrm{H}$ ), 7.49 (dd, $J=7.3,1.0 \mathrm{~Hz}, 1 \mathrm{H}), 7.46$ (dd, $J=8.4,1.5 \mathrm{~Hz}, 1 \mathrm{H}), 6.68$ (d, $J=7.7 \mathrm{~Hz}, 1 \mathrm{H}$ ), $5.48(\mathrm{dt}, J=5.8,1.1 \mathrm{~Hz}, 1 \mathrm{H}), 5.38(\mathrm{dt}, J=5.7,1.1 \mathrm{~Hz}, 1 \mathrm{H}), 4.15$ (m, 2H), $3.82(\mathrm{~s}, 2 \mathrm{H})$, 2.82 (s, 6H), 2.25-2.21 (m, 2H), 2.10-2.07 (m, 2H), 1.76 (s, 3H), 1.68 (s, 3H); ${ }^{13} \mathrm{C}$ NMR $\delta$ 144.1, 139.1, 133.1, 131.8, 130.3, 130.1, 128.9, 126.3, 126.0, 124.4, 123.8, 122.5, 114.1, 105.8, 59.3, 51.9, 39.1, 37.4 (2C), 26.0, 16.2, 14.9; HRMS (FAB) calcd for $\mathrm{C}_{22} \mathrm{H}_{31} \mathrm{~N}_{2} \mathrm{O}_{3} \mathrm{~S}$ $(\mathrm{M}+\mathrm{H})^{+}$403.2055, found 403.2059. Anal. Calcd for $\mathrm{C}_{22} \mathrm{H}_{30} \mathrm{~N}_{2} \mathrm{O}_{3} \mathrm{~S} 1 / 4 \mathrm{H}_{2} \mathrm{O}$ : C, 64.92; $\mathrm{H}$ 7.55; N, 6.88. Found: C, 65.10; H 7.48; N, 6.76.

Sulfonamide 25. $N$-Chlorosuccinimide (568 mg, $4.26 \mathrm{mmol}$ ) was dissolved in $\mathrm{CH}_{2} \mathrm{Cl}_{2}(16 \mathrm{~mL})$ and the solution was cooled to $-30{ }^{\circ} \mathrm{C}$ in an acetonitrile/dry ice bath. Dimethyl sulfide (0.34 mL, $4.64 \mathrm{mmol}$ ) was added dropwise by syringe, and the reaction mixture was allowed to warm to $0{ }^{\circ} \mathrm{C}$ in an ice bath and stirred for 5 min. After the 
reaction mixture was cooled to $-40{ }^{\circ} \mathrm{C}$, a solution of compound $24(1.56 \mathrm{~g}, 3.87 \mathrm{mmol})$ in $\mathrm{CH}_{2} \mathrm{Cl}_{2}(4 \mathrm{~mL})$ was added dropwise by syringe at $-40{ }^{\circ} \mathrm{C}$. The suspension was allowed to warm to $0{ }^{\circ} \mathrm{C}$ in an ice bath and stirred for $3 \mathrm{~h}$, and then allowed to warm to rt and stir for additional 15 min. The mixture was poured into cold brine and extracted with $\mathrm{CH}_{2} \mathrm{Cl}_{2}$. The organic layers were combined and dried over $\mathrm{MgSO}_{4}$. After the solvent was removed under reduced pressure, the product was dried in vacuo for $1 \mathrm{~h}$, and then was used directly in the next step without further purification.

Sulfonamide 32. After compound 30 (237 mg, $0.59 \mathrm{mmol}$ ) was dissolved in $\mathrm{ClCH}_{2} \mathrm{CH}_{2} \mathrm{Cl}(2.4 \mathrm{~mL}), 4 \AA$ molecular sieves were added and after 30 min aldehyde $31^{48,55}$ (350 mg,1.63 mmol) and acetic acid $(0.28 \mathrm{~mL}, 4.86 \mathrm{mmol}$ ) were added to the reaction mixture. The reaction mixture was stirred for $5 \mathrm{~min}$ at $\mathrm{rt}$ and then treated with solid $\mathrm{NaBH}(\mathrm{OAc})_{3}(763 \mathrm{mg}, 3.60 \mathrm{mmol})$. The solution was allowed to stir at rt until the reactants were consumed as monitored by TLC analysis $(\sim 2 \mathrm{~h}$, and then quenched by addition of $5 \% \mathrm{NaHCO}_{3}$ dropwise at $0{ }^{\circ} \mathrm{C}$. The solution was extracted with ether, dried $\left(\mathrm{MgSO}_{4}\right)$, and concentrated to afford a green-yellow oil. Purification by flash column chromatography (hexane:EtOAc, 95:5) gave compound 32 (271 mg, 89\%) as a greenyellow oil that was used directly in the following reaction: ${ }^{1} \mathrm{H}$ NMR $\delta 8.21$ (dd, $J=7.5$, $1.0 \mathrm{~Hz}, 1 \mathrm{H}), 8.09$ (d, $J=8.6 \mathrm{~Hz}, 1 \mathrm{H}), 8.04$ (d, $J=8.7 \mathrm{~Hz}, 1 \mathrm{H}), 7.50-7.44$ (m, 2H), 6.68 (d, $J=7.7 \mathrm{~Hz}, 1 \mathrm{H}), 5.68-5.64$ (m, 1H), 5.60-5.55 (m, 1H), 4.27 (d, $J=6.8 \mathrm{~Hz}, 2 \mathrm{H}$ ), 3.85 (s, 2H), 3.24 (t, $J=6.6 \mathrm{~Hz}, 2 \mathrm{H}), 2.84$ (s, 3H), 2.22-2.16 (m, 2H), 1.77 (s, 3H), 1.74 (s, 3H), 1.67 (s, 6H), 0.90 (s, 9H), 0.07 (s, 6H); ${ }^{13} \mathrm{C}$ NMR $\delta$ 144.2, 134.5, 133.4 (2C), 130.2, 130.2, 129.1, 126.7, 126.1, 125.5, 124.7, 122.8, 114.4, 106.1, 60.2, 51.8, 49.4, 34.5, 34.1, 26.2 (3C), 24.7, 18.7, 15.3, 14.0, -4.9 (2C). 
Geranylgeraniol analogue 33. To a solution of compound 32 (250 mg, 0.48 mmol) in THF ( $4 \mathrm{~mL}$ ) was added TBAF (1 M solution in THF, $2.40 \mathrm{mmol})$ and the solution was allowed to stand for $2 \mathrm{~h}$ at $0{ }^{\circ} \mathrm{C}$ to $\mathrm{rt}$. The reaction was quenched by addition of saturated $\mathrm{NH}_{4} \mathrm{Cl}$ (aq) and extracted with EtOAc. The combined organic layers were washed with brine and dried $\left(\mathrm{MgSO}_{4}\right)$. After concentration in vacuo, the residue was purified by column chromatography (hexane:EtOAc, 7:3) to afford compound 33 (78.6 mg, 41\%) as a green-yellow oil: ${ }^{1} \mathrm{H}$ NMR $\delta 8.19$ (dd, $J=7.4,1.1 \mathrm{~Hz}$, 1H), 8.10-8.02 (m, 2H), 7.50-7.44 (m, 2H), 8.65 (d, $J=7.7 \mathrm{~Hz}, 1 \mathrm{H}), 5.76-5.71(\mathrm{~m}, 1 \mathrm{H})$, 4.99-4.93 (m, 1H), 4.25 (d, $J=6.8 \mathrm{~Hz}, 2 \mathrm{H}$ ), 3.88 (s, 2H), 2.86 (s, 3H), 2.25-2.17 (m, 2H), 1.81 (s, 3H), 1.60 (s, 3H), 1.54 (s, 3H); ${ }^{13} \mathrm{C}$ NMR $\delta$ 144.0, 135.7, 134.9, 134.5, 130.1, 129.0, 125.9, 125.0 (2C), 124.6, 122.8, 120.2, 114.6, 106.0, 59.4, 51.5, 49.6, 34.3, 26.9, 25.9, 17.9, 15.3 .

Chloride 34. $N$-Chlorosuccinimide $(26.7 \mathrm{mg}, 0.2 \mathrm{mmol})$ was dissolved in $\mathrm{CH}_{2} \mathrm{Cl}_{2}(0.8 \mathrm{~mL})$ and allowed to cool to $-30{ }^{\circ} \mathrm{C}$ in an acetonitrile/dry ice bath. Dimethyl sulfide (20 $\mu \mathrm{L}, 0.22 \mathrm{mmol}$ ) was added dropwise by syringe, the reaction mixture was allowed to warm to $0{ }^{\circ} \mathrm{C}$ in an ice bath, and stirred for $5 \mathrm{~min}$. After the reaction mixture was cooled to $-40{ }^{\circ} \mathrm{C}$, a solution of alcohol $33(73 \mathrm{mg}, 0.18 \mathrm{mmol})$ in $\mathrm{CH}_{2} \mathrm{Cl}_{2}(0.2 \mathrm{~mL})$ was added dropwise by syringe at $-40{ }^{\circ} \mathrm{C}$. The suspension was allowed to warm to $0{ }^{\circ} \mathrm{C}$ in an ice bath and stirred for $3 \mathrm{~h}$, and then allowed to warm to rt and stirred for an additional 15 min. The resulting mixture was poured into cold brine, extracted with $\mathrm{CH}_{2} \mathrm{Cl}_{2}$ and then the organic layers were combined and dried $\left(\mathrm{MgSO}_{4}\right)$. After the solvent was removed under reduced pressure, the residue was dried in vacuo for $1 \mathrm{~h}$ to yield 
compound 34 as a green-yellow oil. This material was carried to the next step without further purification. 